thogenic power on the rabbit, that colibacillosis enteritis exits in this species. Enteropathogenic strains belong to $02,08,020,039$ and 0106 groups in the newborn rabbit and to $02,049,085$, oro3 and or 32 groups in the fattening rabbit.

\title{
IMPORTANCE OF NEPHROPATHIES IN THE RABBIT
}

\author{
J. VAISSAIRE, Cl. MAIRE, L. RENAULT et J. P. LABADIE \\ avec la collaboration technique d'E. Le Bourhis, M. Auvray et C. Pianel \\ Laboratoires vétérinaires Sanders, \\ 17, Quai de l'Industrie, \\ 91260 Juvisy sur Orge
}

Among 669 rabbits received at the laboratory during 1972 about 56 p. roo exhibited nephritis lesions and 60 suffered from " uremic syndrome ". Primary kidney lesions were caused either by microbic or parasitic diseases, or poor management conditions bringing about serious digestive troubles, or, at last, uncontrolled use of medications. Epithelial nephritis bringing about an important mortality by * uremic syndrome ", high levels of urea, reaching in certain cases $4.5 \mathrm{~g}$ per liter of serum, was associated with hyperkaliemia reaching $23 \mathrm{mEq}$ per liter and causing rapid death by heart stopping. To cope with severe nephropathy that may kill up to $50 \mathrm{p}$. Ioo of flocks, farmers should take into consideration the importance of good management practises and good sanitary conditions of their animals.

\section{III. - Physiology}

\section{COMPARISON OF THE HEPRODUCTIVE BEHAVIOUR OF DOES MATED AT DIFFERENT TIME INTERVALS AFTER PARTURITION}

\author{
Maryse SELME et M. PRUD'HON \\ Station de Physiologie animale, I. N.R.A., \\ E. N.S.A., Place Viala, \\ 34060 Montpellier Cedex
}

The effect on ovulation, implantation and embryo survival of the time interval between parturition and mating was studied in 182 primiparous rabbits. The rabbits were mated either on day I (lot I) or on day Io (lot Io) and killed on day IO, I6, 20, 24 or 28 post-coitus. The frequencies of ovulation and implantation were determined, the numbers of corpora lutea (C. L.) 